\title{
Technology as an Emerging Educational Tool for Tourism Information Sourcing: A Content Analysis 2006 to 2018
}

\author{
https://doi.org/10.3991/ijes.v7i2.10772 \\ Tinashe Chuchu \\ University of Pretoria, South Africa \\ tinashe.chuchu@up.ac.za
}

\begin{abstract}
Emerging technologies present an increasing assortment of approaches to support and enrich learning environments. The purpose of this study was therefore to investigate the impact of technology as an educational tool for tourism information. Based on content analysis a total of 22 studies on technology and tourism published over a 12 year period from 2006 and 2018 were examined, systematically presented and discussed. The presented study was qualitative in nature. It highlighted the extent to which travellers have embraced technology for tourism information searches and sources. Recurring trends based on review of literature were identified. Two main themes were observed, first, being technology in tourism education and second, being the use of user-generated content in tourism. In conclusion it can be established that learning about travel and tourism through social media was not only for travellers who depend on tourism information but also tourism companies who depend on traveller reviews and marketing promotions for their facilities.
\end{abstract}

Keywords - Technology, social media, education, information, tourism

\section{$1 \quad$ Introduction}

Emerging technologies present an ever escalating variety of means to support and enrich learning environments [14]. The use of social media in facilitating the education process is neither a new phenomenon nor restricted to a single field of study as it has also been adopted in various contexts which include, medical education [4]. This then shows the amount of attention that education through social media has received and why it is considered relevant in facilitating and enhancing the educational process. Traveller's tourism education through technology has received attention from tourism scholars in the past. For example [23], used the term "online tourism" information space" to describe the collection of electronic content available for travel information [34]. The present study focuses on the introduction of technologies such as social media in educating beneficiaries of tourism referring to travelers and tourism organisations. However, other educational sectors have recently seen changes due to the introduction of technology. For example, the introduction of technology in music 
education in China [40], technology use to induce creativity in learning [31] and the use of e-learning at universities [1].

The role of social media in tourism has been considered as one of the most significant influencers of travellers education and decision making [15]. [19] defined social media as online groups of individuals who hold common interests. [37] posited that research related to tourism management in the future will likely be driven by the opportunities and challenges brought about by the unabated growth of data and information. The internet has fundamentally reshaped the way consumers learn about the tourism information and their approach to the way they plan their travel [3]; [40]. Social media is considered to be emerging as a prominent element of destination marketing by tourism organisations [13].

According to [25] social media platforms offer researchers the ability to reach a large sample efficiently and cheaply thus emerging as a prominent research tool for tourism researchers. The emergence of social media has introduced an innovative approach in administering surveys for tourism research [25]. According to [34] travel seekers more likely to cross-shop, price check, utilise the word of mouth and on-line reviews as this will influence the online travel purchase decision. Negative word of mouth can have an overwhelming impact upon a destination's image, as dissatisfied visitors spread unflattering comments related to their experiences (Morgan, Pritchard \& Piggott, 2003; [17]. In addition, [17] established in their study that traveller decision-making was improved by electronic word of mouth such as travel blogs. Online travelers greatly benefit from social media websites ability to allow for the creation of user-generated content [11]; [13]; [35]. Travellers have become increasingly dependent on internet search engines for their consumption of internet travel [6] Information and communication technology has progressively gained relevance and significance in the marketing of the tourism and travel industry [39]. In addition, it was suggested in the study by [39] that social media has literally risen to become a contract aspect of society thus attracting attention from industries such as the tourism sector. Social media is progressively becoming as part of tourism practices affecting destinations and businesses [20]. According to [21] social media has fundamentally altered communication in tourism industry. The research in question therefore looks-into how it has been used to further the education of tourism. In the sections that follow the case for the research problem is made. In addition, the literature review, methodology, results and discussion is provided.

\subsection{Statement of the problem}

As indicated by [13] destination marketing oganisations have not been fully utilising social media in relation to interaction and engagement with travellers. Additionally, [13] stated that social media does not receive much respect therefore suffers from underfunding which ultimately limits its impact as an effecting marketing strategy tool. There is a dearth of knowledge and understanding on how to best implement new media in tourism and hospitality education. To this end this research seeks to expand on investigating the usefulness of technology specifically social media as an educational tourism tool and source of information for travellers. 


\section{$2 \quad$ Literature Review}

\subsection{Technology as an educational tool in tourism}

Recent developments in technology have altered the way humans think work and live [2]. This sentiment is echoed by [37] who suggested that information technology continues to move human society. In addition, [37] suggested that one cannot separate the relationship between information technology and tourism from the global, societal view of technology. [19] posited that online social travel networking is also advancing the way tourists plan their trips as this allows users to engage and provide reviews on hotels or on local tourist attractions. This therefore re-enforces how tourists consider technology through social media as an educational outlet for learning and receiving tourism material.

The growth of Internet applications on hospitality and tourism has led to enormous amounts of consumer generated online reviews on different travel-related facilities [34]. The education of tourism though the use of technology is not only restricted to consumers but also applies to tourism organisations. This assertion is supported by [3] tourism organisations should collect traveller information at each stage of service, before, during, and after a visit in order to understand consumer behaviour of tourists. This then suggests that education of tourism through technology indeed stands to benefit both tourists and tourism organisations. In addition, [3] suggested that satisfaction of tourists greatly depends on the accuracy and comprehensiveness of the information that is provided to them.

According to [5] social media platforms are resonating more with travellers and business alike. This therefore supports [34] postulation that numerous travellers consult online reviews prior to making (online) travel arrangements. Tourism consumers learn about travel destinations from various social media as suggested by [5] who stated that travels utilise platforms like Facebook, Linkedin, Twitter, Youtube, Hi5, blogs, Flickr, WAYN, Scribd, Bebo, with Facebook being the most popular outlet for travellers education of holiday destinations. Interpersonal communications have been considered to be significantly influential in the tourism industry for a long time [17]. Due to the increased competition in the tourism industry, loyalty among online travellers has been considered vital to hotel suppliers' success among online prospects is integral to hotel suppliers' success [34].

The internet has enabled marketers to enhance the efficiency and effectiveness of communication with travellers as well as increased acquisition and retention of customers [22]; [36]; [17]. According to [11]; [24]; [40] social media websites, such as blogs, virtual communities, wikis, social networks, collaborative tagging, and media files shared on sites such as YouTube and Flickr, have gained considerable acceptance from online travelers' use of the internet. This continues to re-enforce how travelers continue to appreciate receiving educational tourism information through the use of technology. [7] established the most US households rely on internet search engines as their primary source for receiving information relating to travel and vacation planning. Internet travel blogs seem to be the most discussed social media platform in the tourism literature [33]; [5]. 


\subsection{Social media in education}

According to the [18] social media has become a trusted source for information, education and a forum that enable organisations to interact with audiences. Facebook and other social media platforms have been praised as delivering the promise of new, socially engaged educational experiences for students in university and other educational sectors [8]. This then suggests that social media as an educational medium is not only limited to informal education/ learning as was the context of this research but also in formal education settings such as in [8] who highlighted the extent to which undergraduate students (learners) gained from learning through unconventional means such as social media. The diagram below is an illustration of a technology fused learning environment depicting the amount of information a single learner could be potentially exposed to while online.

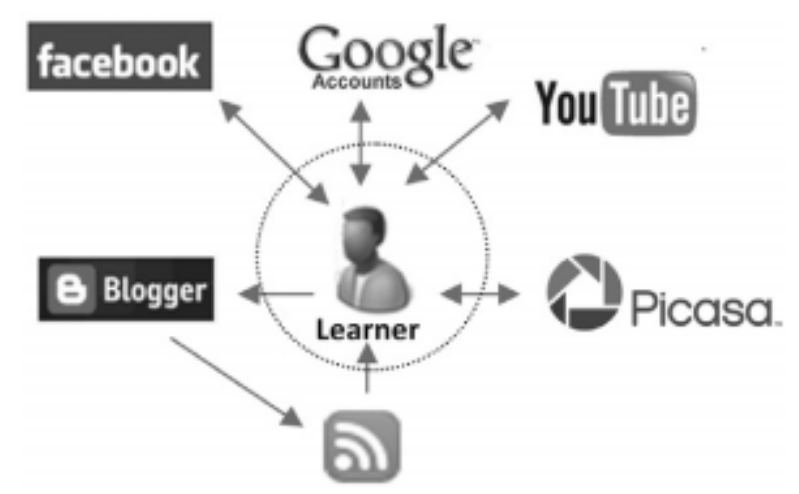

Fig. 1. Online Learning Environment for a Learner

Source: Adapted from [8]

[10] social media has the capacity to transcend formal and informal learning through participatory digital environments. The following benefits of using social media for educational purposes were therefore provided by the [18]:

- Engagement with experts on topics through social media

- Institutions connect with students through social media sites such as YouTube and Facebook

- It aids and supports the research process

- Provides improved learning management systems

- Students can develop social credibility

Information and communication technology viewed as an essential aspect of the modern world [38]. It could be assumed that not many people have failed to recognise the surgence of social media most notably the likes of websites such as Facebook, Twitter, YouTube and Wikipedia [25]. This then highlights the possible if not endless possibilities for social media in contemporary human life. This then aids in making 
the case to why social media also become relevant for travellers who seek for information regarding vacations.

According to [32] the rapid advancement of social networking sites has drawn the attention of scholars and researchers to study this phenomenon in different disciplines. In addition, [32] stated that hospitality and tourism research related to the use of electronic communication channels has emphasised the significance and relevance of technology to the hospitality and tourism industry [15]. Tourism education through technology is not only restricted to travellers but also tourism organisations. For example in their study, [9] through experimental designed established that geotagged photos by tourists were more dispersed than that of locals suggested that the tourists were more spread across the same regions they were studying. This shows how tourism organisations and scholars use technology to learn about tourism through the utilisation of modern technology.

\section{$3 \quad$ Research Methodology}

The overall objective of this paper is to build upon previous research into social media use for tourism research through a systematic analysis of studies published over a 12 year period from 2006 to 2018. To obtain data suitable for the research a total of 22 articles were reviewed and analysed for content analysis following [30] who reviewed the 22 articles for their research. This was to achieve an objective comprehension of the studies that reviewed the use of social media as a tourism education tool for travellers. Search engines that include Google scholar, Ebsco host and science direct were utilised to obtain relevant and suitable articles. Each of the selected papers was scrutinised in terms of year of publication, methodology, data analysis and sample or unit of analysis, following [29]; [28]. In line with the content analysis methodology proposed by [28] this paper reviewed research methods adopted for the articles utilised for the purposes of this study.

\section{$4 \quad$ Findings}

The table below presents prior research on social and tourism research that was used for content analysis in the present study. Authors/ sources, research methods and main findings for each articles utlised in identifying common trends and themes were presented.

Table 1. Review and Analysis on Social Media and Tourism Research

\begin{tabular}{|c|l|l|}
\hline $\begin{array}{c}\text { Author(s) } \\
\text { / Source }\end{array}$ & \multicolumn{1}{|c|}{ Method } & \multicolumn{1}{c|}{ Main Finding } \\
\hline$[37]$ & Quantitative & $\begin{array}{l}\text { Evolution of tourism research from a primarily a marketing-driven tool to a } \\
\text { knowledge creation tool due to new technology. }\end{array}$ \\
\hline$[3]$ & Qualitative & $\begin{array}{l}\text { The advancement of technology through the internet has changed dramatically } \\
\text { the market conditions for tourism organisations. }\end{array}$ \\
\hline$[40]$ & Quantitative & Social media is responsible for s significant amount of travel information \\
\hline
\end{tabular}


Paper-Technology as an Emerging Educational Tool for Tourism Information Sourcing A Content ...

\begin{tabular}{|c|c|c|}
\hline & & searches. \\
\hline [7] & Quantitative & $\begin{array}{l}\text { Majority of Americans use internet search engines for travel and holiday infor- } \\
\text { mation. }\end{array}$ \\
\hline [24] & Qualitative & Travel blogs show multifaceted aspects of a visitor's experience at a destination \\
\hline [17] & Qualitative & Electronic word of mouth enhances the consumer decision-making process. \\
\hline [25] & $\begin{array}{l}\text { Mixed-mode } \\
\text { survey }\end{array}$ & $\begin{array}{l}\text { Social media affordable and powerful tool for targeting respondents for tourism } \\
\text { research. }\end{array}$ \\
\hline [14] & Case study & $\begin{array}{l}\text { Facebook supports collaborative learning and engaging environments about } \\
\text { sustainable tourism. }\end{array}$ \\
\hline [34] & Qualitative & $\begin{array}{l}\text { The number of online reviews can substantially improve the use of a hotel by } \\
\text { travellers }\end{array}$ \\
\hline [23] & Qualitative & $\begin{array}{l}\text { Tourists' planning can be critiqued into a series of steps reflecting the specific } \\
\text { problem being addressed. }\end{array}$ \\
\hline [26] & Quantitative & $\begin{array}{l}\text { Content a tourism company posts on its Facebook wall affects customer partici- } \\
\text { pation. }\end{array}$ \\
\hline [33] & Qualitative & $\begin{array}{l}\text { Technology now has increased power through blogs thus reducing powers of } \\
\text { institutions/marketers. }\end{array}$ \\
\hline$[20]$ & Quantitative & Motivational factors vary according to type of content and type of social media. \\
\hline [21] & Qualitative & $\begin{array}{l}\text { Information technology and Web } 2.0 \text { applications have a significantly substantial } \\
\text { effect on tourism }\end{array}$ \\
\hline [19] & Quantitative & $\begin{array}{l}\text { Due web platforms most tourists prefer to book hotels online creating new } \\
\text { competition the need for more advanced business models }\end{array}$ \\
\hline [32] & Quantitative & $\begin{array}{l}\text { Hospitality and tourism education policy makers are encouraged to engage with } \\
\text { students through social media platforms for knowledge sharing. }\end{array}$ \\
\hline [9] & $\begin{array}{l}\text { Experimental } \\
\text { design }\end{array}$ & $\begin{array}{l}\text { Photo-sharing services revealed that distribution patterns of locals were different } \\
\text { from tourists and these distribution patterns affect tourism management and } \\
\text { potential visitors. }\end{array}$ \\
\hline$[5]$ & Qualitative & $\begin{array}{l}\text { National tourism organisations are becoming more dependent on social media } \\
\text { across the globe }\end{array}$ \\
\hline [12] & Qualitative & $\begin{array}{l}\text { The benefit social media offer to electronic learning strategies has the potential } \\
\text { to provide social support, which is a supportive environment that is useful in } \\
\text { advancing tourism education. }\end{array}$ \\
\hline [16] & $\begin{array}{l}\text { Experimental } \\
\text { design }\end{array}$ & $\begin{array}{l}\text { Social media could potential provide a frame for student preparation, support in } \\
\text { project working methods and challenge students in engaging learning environ- } \\
\text { ments }\end{array}$ \\
\hline [39] & $\begin{array}{l}\text { Mixed Method } \\
\text { Case study and } \\
\text { Survey }\end{array}$ & $\begin{array}{l}\text { Social media in education can be a valuable marketing tool as it makes stories of } \\
\text { a school's students and alumni more human and enjoyable. This then then gen- } \\
\text { erates loyalty from the schools' past, current and future students. }\end{array}$ \\
\hline [15] & Qualitative & Findings strategic importance of social media for tourism competitiveness. \\
\hline
\end{tabular}

\section{Discussion of the Findings}

As presented in table 1 above content analysis was conducted on 22 literature sources as stipulated in the methodology section of this paper. The authors were provided together with the research method and findings for each of the 22 studies utilised. This research spanned over a 12 year period from 2006 to 2018 critiquing published research on the impact that the introduction of technology especially social media has had on tourism education. It could be observed that the majority of the papers were quantitative followed by qualitative research, experimental design and only one mixed method approach based study. A total of 7 studies were quantitative while 9 were qualitative in nature. 2 studies were based on the mixed methods while 2 
were based on experimental design. A recurring finding was that the introduction of technology in tourism ushered in a ground-breaking advancement to the tourism industry as this improved how travellers accessed information. In general it could be observed that all the studies analysed for this research had unique contributions and context but the common idea was that the importance and relevance of the use on technology mainly social media in tourism education was an undeniable reality. Tourism organisations were seen to constantly be searching for relevance and competitive advantage and this was possible exacerbated by the increase used and impact of social media use in tourism. For instance the one of the central findings of [15] was the recognition of the strategic importance of social media for tourism competiveness by tourism organisations. This was however in contrast to other studies such as [39], who viewed social media in education as being purely "social" as described by the word. They study posited that social media was not only useful in education but still remained as a social tool for people to communicated

\subsection{Trends and themes observed from content analysis}

The first trend identified in the study was the increased dependency of travellers on social media from both the tourism companies and travellers. The general theme associated with this trend was "technology in tourism education". This dependency was two-fold. First, tourism companies rely on reviewer ratings online as this will encourage travellers to book with their facilities. Second, travellers and holiday goers relied on social media to receive details about a tour operator, holiday accommodation provider (e.g. hotels and resort) online as this was a convenient platform that allowed for instant feedback and ease of use in term of making reservations and payments. Additionally, the reviews on social media sites helped educate travellers on the quality and standards of services that the hotels and tourism facilities (adventure parks) would have provided past travellers.

The second trend was that education through user generated content was found to be a recurring finding across all the analysed studies. The general theme associated with this trend was "the use of user-generated content in tourism". This was regardless of nature of the study whether it was a quantitative, qualitative and experimental design study. This was a trend observed in a number of articles reviewed and possibly due to the popularity of user generated content (such as Youtube, Facebook and Twitter) organisations now relied on positive reviews from travellers who would share their experiences with the public.

\section{Contribution of The Research}

This paper presented a qualitative methodology through content analysis of research published on the use of social media in tourism education. It established that the introduction of technology has significantly altered and enhanced the manner in which travels learn and consume tourism information. The implication of receiving customer reviews on a public platform such as online reviews was that travel organi- 
sations were now compelled to act upon the reviews. In conclusion it can be established that learning about travel and tourism social media was not only for travellers who depend on tourism information but also tourism companies who depend on traveller reviews and promotion of their facilities. Technological developments and teachings have enabled learners to become co-producers of the knowledge delivered to them [27]; Greenhow \& Lewin, 2016). It could be said that this study has made an effort towards contribution to the discussion that technology advancement and learning by tourists has made them co-creators of travel and holiday advertising as they provide reviews online that in-turn impact tourism and vacation providing companies [27]; Greenhow \& Lewin, 2016).

\section{Conclusion and Future Research}

This study reviewed multiple sources that re-enforced the notion that consumption of tourism information now greatly depends on technology through the internet and outlets that include social media. This study highlighted the extent to which travellers have embraced tourism education through the use of technology. Further research suggestions would be to have comparison studies were tourism research education before the introduction of technology and current tourism education studies that highlight the impact of technology in tourism education. This would help contexualise how much progress and challenges technology has brought to human society and the extent to which consumers have rejected or accepted the introduction of technology in receiving information and online payment options for their travels and holidays. In this study research on the use of technology in tourism education was reviewed from a broad perspective. It would be interesting if future tourism scholars should also consider conducting research on tourism education through technology from a more refined specific point of view. For example researching specific countries or regions and assessing the impact that social media and other various technologies have had on travellers to those specific regions. Lastly, research that focuses on the amount of revenue gained or lost through the dependence on or the increased use of social media in educating travellers should also be conducted. This will help make the economic case for tourism organisations to decide whether or not to implement such technologies and strategies.

\section{References}

[1] Almarabeh, T. (2014). Students' Perceptions of E-learning at the University of Jordan. International Journal of Emerging Technologies in Learning (iJET), 9(3), 31-35.

[2] Bahati, B., Fors, U., Hansen, P., Mukama, E., \& Nouri, J. (2019). Measuring Learner Satisfaction with Formative e-Assessment Strategies. International Journal of Emerging Technologies in Learning. 14 (7), 61-78. https://doi.org/10.3991/ijet.v14i07.9120

[3] Buhalis, D., \& Law, R. (2008). Progress in information technology and tourism management: 20 years on and 10 years after the Internet-The state of eTourism research. Tourism management, 29(4), 609-623. https://doi.org/10.1016/j.tourman.2008.01.005 
Paper-Technology as an Emerging Educational Tool for Tourism Information Sourcing A Content ...

[4] Cheston, C. C., Flickinger, T. E., \& Chisolm, M. S. (2013). Social media use in medical education: a systematic review. Academic Medicine, 88(6), 893-901. https://doi.org/10.1097/acm.0b013e31828ffc23

[5] Dwivedi, M., Yadav, A., \& Venkatesh, U. (2011). Use of social media by national tourism organizations: a preliminary analysis. Information Technology \& Tourism, 13(2), 93-103. https://doi.org/10.3727/109830512x13258778487353

[6] eMarketer. (2006) Online Travel Worldwide. http://www.emarketer.com/Report.aspx?travel_dec05\&tab=Toc. . Accessed 16.01.18.

[7] eMarketer. (2008). First summer vacation stop: the Internet. http://www.

[8] emarketer.com/Article.aspx?id1/41006344\&src1/4article1_newsltr. Accessed 02.01.18.

[9] Friesen, N., \& Lowe, S. (2012). The questionable promise of social media for education: Connective learning and the commercial imperative. Journal of Computer Assisted Learning, 28(3), 183-194. https://doi.org/10.1111/j.1365-2729.2011.00426.x

[10] García-Palomares, J. C., Gutiérrez, J., \& Mínguez, C. (2015). Identification of tourist hot spots based on social networks: A comparative analysis of European metropolises using photo-sharing services and GIS. Applied Geography, 63, 408-417. https://doi.org/10.1016/j.apgeog.2015.08.002

[11] Greenhow, C., \& Lewin, C. (2016). Social media and education: Reconceptualizing the boundaries of formal and informal learning. Learning, media and technology, 41(1), 6-30. https://doi.org/10.1080/17439884.2015.1064954

[12] Gretzel, U. (2006). Consumer generated content - trends and implications for branding. Ereview of Tourism Research, 4(3), 9-11.

[13] Hajli, M. N., \& Lin, X. (2014). Developing tourism education through social media. Tourism Planning \& Development, 11(4), 405-414. https://doi.org/10.1080/21568316.2014.883426

[14] Hays, S., Page, S. J., \& Buhalis, D. (2013). Social media as a destination marketing tool: its use by national tourism organisations. Current issues in Tourism, 16(3), 211-239. https://doi.org/10.1080/13683500.2012.662215

[15] Isacsson, A., \& Gretzel, U. (2011). Facebook as an edutainment medium to engage students in sustainability and tourism. Journal of Hospitality and Tourism Technology, 2(1), 81-90. https://doi.org/10.1108/17579881111112430

[16] Leung, D., Law, R., Van Hoof, H., \& Buhalis, D. (2013). Social media in tourism and hospitality: A literature review. Journal of travel \& tourism marketing, 30(1-2), 3-22. https://doi.org/10.1080/10548408.2013.750919

[17] Liburd, J. J., \& Christensen, I. M. F. (2013). Using web 2.0 in higher tourism education. Journal of Hospitality, Leisure, Sport \& Tourism Education, 12(1), 99-108. https://doi.org/10.1016/i.jhlste.2012.09.002

[18] Litvin, S. W., Goldsmith, R. E., \& Pan, B. (2008). Electronic word-of-mouth in hospitality and tourism management. Tourism management, 29(3), 458-468. https://doi.org/10.1016/j.tourman.2007.05.011

[19] London College of International Business Studies (2019) The Role of Social Media in Education retrieved from https://www.lcibs.co.uk/the-role-of-social-media-in-education/ Accessed (2019/04/23)

[20] Miguéns, J., Baggio, R., \& Costa, C. (2008). Social media and tourism destinations: TripAdvisor case study. Advances in tourism research, 26(28), 1-6.

[21] Munar, A. M., \& Jacobsen, J. K. S. (2014). Motivations for sharing tourism experiences through social media. Tourism management, 43, 46-54. https://doi.org/10.1016/j.tourman.2014.01.012 
Paper-Technology as an Emerging Educational Tool for Tourism Information Sourcing A Content ...

[22] Nezakati, H., Amidi, A., Jusoh, Y. Y., Moghadas, S., Aziz, Y. A., \& Sohrabinezhadtalemi, R. (2015). Review of social media potential on knowledge sharing and collaboration in tourism industry. Procedia-social and behavioral sciences, 172, 120-125. https://doi.org/10.1016/j.sbspro.2015.01.344

[23] Osenton, T. (2002) Customer Share Marketing. Upper Saddle River, NJ: Prentice Hall.

[24] Pan, B., \& Fesenmaier, D. R. (2006). Online information search: vacation planning process. Annals of Tourism Research, 33(3), 809-832. https://doi.org/10.1016/j.annals.2006.03.006

[25] Pan, B., MacLaurin, T., \& Crotts, J. C. (2007). Travel blogs and their implications for destination marketing. Journal of Travel Research, 46(1), 35-45. https://doi.org/10.1177/0047287507302378

[26] Paris, C. M. (2013). Surveying "difficult-to-sample" backpackers through Facebook? Employing a mixed-mode dual-frame procedure. Anatolia, 24(1), 75-85. https://doi.org/10.1080/13032917.2012.762319

[27] Pesonen, J. (2011). Tourism marketing in facebook: Comparing rural tourism SME's and larger tourism companies in Finland. In ENTER. 537-546. https://doi.org/10.1007/978-37091-0503-0 43

[28] Selwyn, N. (2012). Social media in higher education. The Europa world of learning, 1, 110.

[29] Šerić, M. (2018). Content analysis of the empirical research on IMC from 2000 to 2015. Journal of Marketing Communications, 24(7), 647-685. https://doi.org/10.1080/13527266.2016.1184708

[30] Šerić, M., \& Gil-Saura, I. (2012b). "La investigación en torno a la comunicación integrada de marketing: Una revisión [Research on Integrated Marketing Communications: A Review]." Cuadernos De Administración 24 (43): 63-92. Created by http://revistas.javeriana.edu.co/ , available at http://revistas.javeriana.edu.co/index.php/cuadernos admon/article/view/3596/2704 , licensed under Creative Commons Attribution 4.0 International Public License CC BY 4.0, https://creativecommons.org/licenses/by/4.0/. https://doi.org/10.25100/cdea.v17i25.159

[31] Seuring, S., \& Gold, S. (2012). Conducting content-analysis based literature reviews in supply chain management. Supply Chain Management: An International Journal, 17(5), 544-555. https://doi.org/10.1108/13598541211258609

[32] Shubina, I., \& Kulakli, A. (2019). Pervasive Learning and Technology Usage for Creativity Development in Education. International Journal of Emerging Technologies in Learning, 14(1). 95-109. https://doi.org/10.3991/ijet.v14i01.9067

[33] Sobaih, A. E. E., \& Moustafa, M. A. (2016). Speaking the same language: the value of social networking sites for hospitality and tourism higher education in Egypt. Journal of Hospitality \& Tourism Education, 21-31. https://doi.org/10.1080/10963758.2015.1127169

[34] Thevenot, G. (2007). Blogging as a social media. Tourism and Hospitality Research, 7(3/4), 282-289.

[35] Tuominen, P. (2011). The influence of TripAdvisor consumer-generated travel reviews on hotel performance. Presented at the 19th annual Frontiers in Service Conference, 1-11

[36] White, N., \& White, P. (2007). Home and away: Tourists in a connected world. Annals of Tourism Research, 34(1), 88-104

[37] Wind, Y., Mahajan, V., \& Gunther, R.E. (2002) Convergence Marketing: Strategies for Reaching the New Hybrid Consumer. Upper Saddle River, NJ: Prentice Hall. 
Paper-Technology as an Emerging Educational Tool for Tourism Information Sourcing A Content ...

[38] Xiang, Z. (2018). From digitization to the age of acceleration: On information technology and tourism. Tourism management perspectives, 25, 147-150. https://doi.org/10.1016/j.tmp.2017.11.023

[39] Yusuf, M. O. (2005). Information and communication technology and education: Analysing the Nigerian national policy for information technology. International education journal, 6(3), 316-321.

[40] Zehrer, A., \& Grabmüller, A. (2012). Social media marketing in tourism education: Insights into the development and value of a social network site for a higher education institution in tourism. Journal of Vacation Marketing, 18(3), 221-228. https://doi.org/10.1177/1356766712449368

[41] Zeng, B., \& Gerritsen, R. (2014). What do we know about social media in tourism? A review. Tourism management perspectives, 10, 27-36. https://doi.org/10.1016/j.tmp.2014.01.001

[42] Zhang, P., \& Sui, X. (2017). Application of digital music technology in music pedagogy. International Journal of Emerging Technologies in Learning (iJET), 12(12), 4-13. https://doi.org/10.3991/ijet.v12i12.7966

\section{Author}

Dr Tinashe Chuchu Ph.D. is a senior lecturer in the Marketing Management Department at the University of Pretoria. His area of research focuses on consumer behavior and tourism. His work has been published and presented in numerous international journals and conferences respectively.

Article submitted 2019-04-30. Resubmitted 2019-06-06. Final acceptance 2019-06-06. Final version published as submitted by the authors. 